\title{
INITIAL GROWTH PERFORMANCE OF VALUABLE TIMBER SPECIES IN SOUTHERN BRAZIL: Araucaria angustifolia, Balfourodendron riedelianum, AND Parapiptadenia rigida
}

Larissa Regina Topanotti ${ }^{*} \odot$, Dionatan Gerber ${ }^{3} \odot$, Oiliam Carlos Stolarski ${ }^{4} \odot$, Bruna Elisa Trentin ${ }^{5} \odot$, $^{\circ}$ Carla $^{\circ}$ Talita Pertille ${ }^{6}$, Luís Paulo Baldissera $\operatorname{Schorr}^{7}{ }^{\circledR}$, Maurício Romero Gorenstein ${ }^{5} \mathbb{C}^{-}$, Marcos Felipe Nicoletti $^{2} \odot$ and Fernando Campanhã Bechara ${ }^{5}$

\footnotetext{
${ }^{1}$ Received on 05.10.2018 accepted for publication on 23.07.2019.

${ }^{2}$ Universidade do Estado de Santa Catarina, Programa de Pós-Graduação em Engenharia Florestal, Lages, SC - Brasil. E-mail: <larissatopanotti@ yahoo.com.br $>$ and $<$ marcos.nicoletti@udesc.br $>$.

${ }^{3}$ Instituto Politécnico de Bragança, Programa de Pós-Graduação em Recursos Florestais, Bragança, Portugal. E-mail: <dionatan_gerber@hotmail. com>.

${ }^{4}$ Casa da Floresta Assessoria Ambiental, Piracicaba, SP - Brasil. E-mail: <oiliam@casadafloresta.com.br>.

${ }^{5}$ Universidade Tecnológica Federal do Paraná, Campus Dois Vizinhos, Dois Vizinhos, PR - Brasil. E-mail: <brunaelisatrentin@gmail.com>, $<$ mauriciorg@utfpr.edu.br> and <bechara@utfpr.edu.br>.

${ }^{6}$ Klabin S.A, Otacílio Costa, SC - Brasil. E-mail: <carla pertille@hotmail.com>.

${ }^{7}$ Universidade Federal de Lavras, Programa de Pós-Graduação em Engenharia Florestal, Lavras, MG - Brasil. E-mail: <luispaulo_schorr@hotmail. com>.

*Corresponding author.
}

\begin{abstract}
The initial growth of three Brazilian native timber species in the city of Dois Vizinhos-PR, Brazil, was described - Araucaria angustifolia, Balfourodendron riedelianum, and Parapiptadenia rigida, using four non-linear mathematical models (Gompertz, Logistic, Logistic 4P, and Chapman-Richards). In the first 4 years after planting, information about collar diameter $(\mathrm{mm})$, total height $(\mathrm{m})$, crown height $(\mathrm{m})$, and crown diameter $(\mathrm{m})$ was obtained twice a year for 12 individuals per species. Crown area $\left(\mathrm{m}^{2}\right)$ and crown volume $\left(\mathrm{m}^{3}\right)$ were estimated. The growth in these four variables (collar diameter, total height, crown area, and crown volume) was projected using the models, and their fitting was assessed based on the values of the Akaike Information Criterion, the Bayesian Information Criterion, the standard error of estimate, and the coefficient of determination. The models generated excellent statistics for all parameters in all variables, with better statistics for collar diameter (coefficient of determination higher than 0.65 and standard error lower than 30\%) and total height (coefficients of determination higher than 0.72 and standard error lower than $37 \%$ ). Considering the three species, Parapiptadenia rigida showed the fastest growth in all variables (median of $70.97 \mathrm{~mm}$ for collar diameter, median of $4.475 \mathrm{~m}$ for total height, median of $10.35 \mathrm{~m}^{2}$ for crown area, and median of $15.30 \mathrm{~m}^{3}$ for crown volume at 48 months). Longer monitoring periods in this and other experiments are recommended to characterize the growth of these three Brazilian native timber species to adequately describe their performance in timber and forest restoration projects.
\end{abstract}

Keywords: Subtropical Atlantic Forest; Fitting models; Non-linear growth models.

\section{DESEMPENHOINICIALDOCRESCIMENTODE ESPÉCIESMADEIREIRAS NA REGIÃO SUL DO BRASIL: Araucaria angustifolia, Balfourodendron riedelianum E Parapiptadenia rigida}

RESUMO - Foi avaliado o crescimento inicial de três espécies madeireiras nativas do Brasil - Araucaria angustifolia, Balfourodendron riedelianum e Parapiptadenia rigida - em Dois Vizinhos - PR, Brasil, usando quatro modelos matemáticos não lineares (Gompertz, Logistic, Logistic 4P e Chapman-Richards). Ao longo dos quatro anos iniciais após plantio, informações sobre diâmetro do colo (mm), altura total (m), altura de copa (m) e diâmetro de copa $(m)$ foram obtidas semestralmente em doze indivíduos de cada espécie. Foi calculada a área de copa $\left(\mathrm{m}^{2}\right)$ e volume de copa $\left(\mathrm{m}^{3}\right)$ desses indivíduos. O crescimento em termos de diâmetro de colo, altura total, 


\begin{abstract}
área de copa e volume de copa foi projetado usando os modelos, e o ajuste dos mesmos foi avaliado em termos de Critério de Informação Akaike e Critério de Informação Bayesiano, Erro padrão da estimativa e Coeficiente de determinação. Os modelos geraram excelentes estatísticas para todos os parâmetros em todas as variáveis, com melhores estatísticas para diâmetro de colo e altura total. Considerando as três espécies, Parapiptadenia rigida apresentou o crescimento mais rápido em todas as variáveis (mediana de 70,97 mm para o diametro do colo, mediana de 4,475 m para altura total, mediana de 10,35 $\mathrm{m}^{2}$ para área de copa e mediana de 15,30 $\mathrm{m}^{3}$ para volume de copa, aos 48 meses). Um monitoramento mais longo e outros experimentos são recomendados para caracterizar o crescimento dessas três espécies madeireiras nativas brasileiras para descrever seu desempenho para produção de madeira e também para projetos de restauração florestal.
\end{abstract}

Palavras-chave: Floresta Atlântica subtropical; Ajuste de modelos; Modelos não lineares de crescimento.

\section{INTRODUCTION}

Farmers have been discouraged to manage natural forests in Brazil due to factors such as bureaucracy, technical deficiency, little funding, uncertainty related to wood use, and the lack of studies on the Brazilian flora. This has led to the strengthening and spreading of exotic timber species as well as to the conversion of native forests into other land use types, particularly agricultural fields, followed by an ecological and traditional knowledge loss about the use and management of these species (Coradin, et al., 2011).

In Southern Brazil, after the European colonization (from the end of the 19th century to the beginning of the $20^{\text {th }}$ century), many native forest resources have been extremely explored, not only by farmers, but also by companies, aiming to provide raw material for buildings and agriculture and to generate income from timber sale. In this scenario, Araucaria angustifolia (Bertol.) Kuntze, Balfourodendron riedelianum (Engl.) Engl. and Parapiptadenia rigida (Benth.) Brenan had their populations reduced, opening up space for ecological restoration projects (Ruschel, et al., 2003; Coradin, et al., 2011).

Excessive harvesting resulted in the dramatic decline of these species (Ruschel, et al., 2003; Mósena and Dillenburg, 2004; Souza, 2007), and they are now listed as threatened by extinction, for example in the list produced by the Environmental Institute of Parana (IAP, 1995), by the Brazilian Institute of Environment and Renewable Natural Resources - IBAMA (MMA, 2014), or even in the International Union for Conservation of Nature and Natural Resources (IUCN, 2018) Red List of Threatened Species (IUCN, 2018). Araucaria angustifolia has been classified as rare by the IAP, as endangered by the IBAMA, and as critically endangered by the IUCN; $B$. riedelianum has been listed as rare by the IAP, as almost endangered by the IBAMA, and as endangered by the IUCN, while $P$. rigida has not yet been recorded in the lists produced by IBAMA or assessed for the IUCN Red List. However, there is still a lack of knowledge about the initial performance of these Brazilian native timber species in reforestation.

Araucaria angustifolia, Araucariaceae, is a large evergreen Brazilian pine that reaches $50 \mathrm{~m}$ in height and a diameter at breast height ( $\mathrm{dbh}$ ) of $250 \mathrm{~cm}$ or more when adult. Its trunk is straight and almost cylindrical, and it has a moderately dense white-yellowish wood, used for sawmill, lumber, plywood, pulpwood, pulp, and paper. This species was the most commercially important timber species in South Brazil over the last century and the only valuable conifer of natural occurrence in the country. Regarding its cultivation, it highly depends on soil quality and fertility; because of this, in the same climate, A. angustifolia stands can show an annual increment of $26 \mathrm{~m}^{3} \cdot \mathrm{ha}^{-1}$ or only $1 \mathrm{~m}^{3} \cdot \mathrm{ha}^{-1}$. It is also culturally important where it naturally occurs because of its edible seeds (Soares, 1979; Carvalho, 2002a; Zandavalli, et al., 2003; Mósena and Dillenburg, 2004).

Balfourodendron riedelianum, Rutaceae, is a deciduous tree that presents up to $35 \mathrm{~m}$ in height and $100 \mathrm{~cm}$ in dbh when adult. Its trunk is also straight and cylindrical, reaching $15 \mathrm{~m}$ in length. It occurs at elevations from 70 to $1,000 \mathrm{~m}$ and prefers welldrained, deep, and fertile soils. It is mainly found in the Seasonal Semideciduous Forest, where it appears in the forest canopy, in the Seasonal Deciduous Forest, and in Araucaria Forests. The wood is dense

Revista Árvore 2019;43(4):e430404 
and whitish, used for furniture, civil construction, pulpwood, and other purposes (Carvalho, 2004).

Parapiptadenia rigida, Fabaceae, is a semideciduous tree, reaching 20 or $35 \mathrm{~m}$ in height when mature. Its trunk is cylindrical, rarely straight, and slightly tilted. It can be found in several forest types at elevations of 30 to $1,100 \mathrm{~m}$ and with well-distributed rainfall. Its wood is dense, whiteyellowish, highly durable, and largely applied in rural constructions, carpentry, energy, and other purposes (Carvalho, 2002b).

Despite the widespread potential of native timber species, as a consequence of the factors mentioned above, there is little information regarding the silviculture of native tree species (Kageyama and Castro, 1989), particularly in terms of growth, neglecting their potential to establish forest stands. Knowledge about individual tree growth is essential, and the modeling of growth relations should have a data basis which considers such information (Nutto, 2001).

In this sense, studying the silviculture and growth of Brazilian native timber species is crucial to design management and restoration projects for these species. This paper describes the initial growth of three Brazilian native timber species, A. angustifolia, $B$. riedelianum, and $P$. rigida, using mathematic modeling.

\section{MATERIAL AND METHODS}

The study was carried out at the Federal University of Technology - Parana, in the municipality of Dois

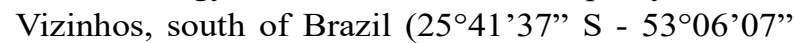
$\mathrm{W})$. The region has an average elevation of $502 \mathrm{~m}$ and deep, moderately fertile soil, characterized as typical dystrophic red oxisol (Embrapa, 2006). The climate is classified as Cfa subtropical, with the occurrence of frosts and the absence of a dry season. The average temperature of the coldest month is below $18^{\circ} \mathrm{C}$ and that of the warmest month is above $22^{\circ} \mathrm{C}$; average annual temperature ranges between 19 and $20^{\circ} \mathrm{C}$ (Alvares, et al., 2014). The vegetation is classified as an ecotone of Araucaria Forest influenced by Seasonal Semideciduous Forest; both forest types belong to the Atlantic Forest biome.

In the experimental area, 70 native trees were planted in December 2010, with 30-50-cm high seedlings distributed in four plots of $40 \times 50 \mathrm{~m}$, resulting in an area of $8,000 \mathrm{~m}^{2}$. In each plot, 360 seedlings were planted, divided into 180 plants of early pioneer species (10 spp.) and 180 plants of non-pioneer species (60 spp.). The pioneer and nonpioneer species were switched within the lines, with a spacing of $3 \mathrm{~m}$ between lines and $2 \mathrm{~m}$ between plants. We assessed the three non-pioneer species, $A$. angustifolia, $B$. riedelianum, and $P$. rigida, each with 12 (3 x 4) individuals planted, resulting in 36 trees evaluated.

As fertilization, $36 \mathrm{~g}$ of NPK fertilizer (5-20-10) were used per plant, and hydro retainer was applied into the holes. The seedlings were protected with cardboard mulching and received cover fertilization of $40 \mathrm{~g}$ of urea per plant and year. Biannually, weeds were controlled by cutting, followed by chemical weeding until the third year.

Data collection started in May 2011, followed by biannual evaluations (one per semester). The collar diameter measurements were taken using a digital pachymeter, which was positioned on the plant collar next to the soil surface. To standardize the measurements, the direction of the plot's greater length was used as reference for the pachymeter positioning.

The variables total height and crown height were measured using a graduated scale of $10 \mathrm{~m}$, with 0.05 $\mathrm{m}$ intervals. The equipment was positioned vertically as close as possible to the plant, settling its base on the soil level. Total height was considered as the distance between the plant's basis to the highest branch and crown height as the length between the plant's basis and its first branch fork.

In addition, two measurements of the crown diameter were taken, perpendicularly to one another, using a measuring tape. After that, the crown area was calculated through the ellipse formula: $c a\left(\mathrm{~m}^{2}\right)$ $=d l \cdot d e . \pi / 4$, where ca is the crown area and $d l$ and de are the crown diameters $(\mathrm{m})$ measured. The crown volume was obtained using the following formula: $c v$ $\left(m^{3}\right)=c a^{*} c l$, where $\mathrm{cv}$ is the crown volume, ca is the crown area $\left(\mathrm{m}^{2}\right)$ obtained by the previous formula, and $c l$ is the crown length, obtained by the result of the subtraction of the total height by the crown height.

The meteorological data were collected from the meteorological station at the Federal University of 
Technology, Parana, Dois Vizinhos, to compare the species growth with the temperatures. All data were stored in electronic spreadsheets on Microsoft Office Excel $^{\mathrm{TM}}$, and the mathematical modeling for growth was conducted using the statistical $R$ software ( $R$ Core Team, 2017).

Regarding the growth modeling, four non-linear models were tested to project the growth in collar diameter, total height, crown area, and crown volume in terms of age. The Non-linear Least Square (NLS) and the SelfStart (SS) functions in the R software were used to calculate the initial estimates of the model parameters. It was not possible to generate the Chapman-Richards model parameters in the $\mathrm{R}$ Software, and therefore, the Statistica ${ }^{\mathrm{TM}}$ software was used.

The models used were Gompertz, Logistic, Logistic 4 Parameters, and Chapman-Richards, as described in the following functions:

Gompertz: $\mathrm{y}=\beta_{0} * \mathrm{e}^{-\beta_{1}+\beta_{2 x}}$,

where $\mathrm{y}$ is the predictable variable, $\beta_{0}$ is a numeric parameter representing the asymptote, $x$ represents a numeric vector of values at which to evaluate the model (in this case, age), $\beta_{1}$ is a numeric parameter related to the value of the function at $\mathrm{x}=0$, $\beta_{2}$ represents a numeric parameter related to the scale in the $x$ axis.

$$
\text { Logistic: } y=\beta_{0} /\left[1+\mathrm{e}^{\left(\left(\beta_{1}-\mathrm{x}\right) / \beta_{2}\right)}\right] \text {, }
$$

where $y$ is the predictable variable, $\beta_{0}$ is a numeric parameter representing the asymptote, $x$ is a numeric vector of values at which to evaluate the model (age), and $\beta_{1}$ represents a numeric parameter representing the $\mathrm{x}$ value at the inflection point of the curve. The value of SSlogis will be $A s y m / 2$ at $x \mathrm{mid} ; \beta_{2}$ represents a numeric scale parameter on the input axis.

$$
\text { Logistic } 4 \text { Parameters: } \underset{\left(\left(-\beta_{1}-\mathrm{x}\right) / \beta_{2}\right)}{y=}, \beta_{0} /(1+\mathrm{e}
$$

where $y$ is the predictable variable, $\beta_{0}$ is a numeric parameter representing the horizontal asymptote on the left side (very small values of input), $\beta_{1}$ is a numeric parameter representing the horizontal asymptote on the right side (very large values of input), input represents a numeric vector of values at which to evaluate the model (age), and $\beta_{2}$ is a numeric parameter representing the input value at the inflection point of the curve. The value of SSfpl will be midway between $\mathrm{A}$ and $\mathrm{B}$ at $x \mathrm{mid} ; \beta_{3}$ is a numeric scale parameter on the input axis.

$$
\text { Chapman-Richards: } y=\beta_{0} *[(1-\mathrm{e}
$$

where $y$ is the predictable variable, $\beta_{0}$ is the maximum value for the predictable variable (asymptote), $\beta_{1}$ represents an empirical growth parameter, $x$ represents a numeric vector of values at which to evaluate the model (age), and $\beta_{2}$ is related to the plant's biology (Burkhart and Tomé, 2012).

To evaluate the quality of the model fitting, Akaike's Information Criterion (AIC), the Bayesian Information Criterion (BIC), the standard error of estimate $\left(\mathrm{S}_{\mathrm{yx}}\right)$, and the coefficient of determination $\left(\mathrm{R}^{2}\right)$ were used, all obtained via the $\mathrm{R}$ statistical program (except the BIC for Chapman-Richards model fits, which could not be calculated). For these criteria, the best model would be the one with smaller AIC, BIC, and standard error values and a higher coefficient of determination.

\section{RESULTS}

Regarding the mathematic modeling applied to the growth variables tested, the fit results for each model are detailed in Table 1. Similar values for standard error, coefficient of determination, AIC, and BIC were obtained for all models in all variables tested. Because of this, each variable was better fitted by a different model, so distinct models could be selected to project the growth for each variable. For example, the logistic model was the one that presented the best fitting statistics to estimate the growth in crown area for $A$. angustifolia, collar diameter, total height, and crown volume for $B$. riedelianum, and collar diameter for $P$. rigida. On the other hand, the CP model was the one with the best statistics to estimate collar diameter, total height, and crown area for $A$. angustifolia, crown area for $B$. riedelianum, as well as crown area and volume for $P$. rigida. The Log 4P was the best-fitted model only for total height of $P$. rigida. The Gompertz model was least suitable to predict species growth and was therefore not selected for any of the variables. 
Table 1 - Statistical parameters obtained for the model fitted for collar diameter, total height, crown area, and crown volume for the studied species.

Tabela 1 - Parâmetros estatísticos obtidos para os modelos ajustados para diâmetro de colo, altura total, área de copa e volume de copa para as espécies estudadas.

\begin{tabular}{|c|c|c|c|c|c|c|c|c|c|c|c|c|}
\hline & \multicolumn{4}{|c|}{ A. angustifolia } & \multicolumn{4}{|c|}{ B. riedelianum } & \multicolumn{4}{|c|}{ P. rigida } \\
\hline & GO & LO & LO 4P & $\mathrm{CP}$ & GO & LO & LO 4P & $\mathrm{CP}$ & GO & LO & LO 4P & $\mathrm{CP}$ \\
\hline \multicolumn{13}{|c|}{ Collar diameter } \\
\hline$\beta 0$ & 0.00005442 & 378.529 & \multirow{8}{*}{$\mathrm{NF}$} & 481.982 & 153.437 & 88.627 & 13.43 & 279.575 & 120.65442 & 86.797 & 12.368 & 489.928 \\
\hline$\beta 1$ & 0.1092 & 92.491 & & 0.002426 & 2.83366 & 33.816 & 68.39 & 0.005164 & 2.43689 & 28.554 & 73.739 & 0.002003 \\
\hline$\beta 2$ & 0.9964 & 25.679 & & 1.00121 & 0.9761 & 15.983 & 31.352 & 0.997692 & 0.97009 & 15.177 & 28.407 & 0.830544 \\
\hline$\beta 3$ & & & & & & & 8.246 & & & & 9.342 & \\
\hline Syx & 27.57 & 27.57 & & 26.31 & 28.4834 & 28.3575 & 28.2784 & 29.19 & 29.0221 & 28.9483 & 29.0404 & 29.42 \\
\hline $\mathrm{R}^{2}$ & 0.7617 & 0.7617 & & 0.7294 & 0.6761 & 0.6789 & 0.6848 & 0.6597 & 0.6515 & 0.6533 & 0.6554 & 0.6418 \\
\hline AIC & 628.5725 & 629.5914 & & 388.0349 & 627.5375 & 626.8202 & 627.3225 & 399.6588 & 671.7496 & 671.3215 & 672.8118 & 433.6643 \\
\hline $\mathrm{BIC}$ & 638.4818 & 638.5007 & & & 637.1153 & 636.398 & 639.2947 & & 681.4729 & 681.0447 & 684.9659 & \\
\hline \multicolumn{13}{|c|}{ Total height } \\
\hline$\beta 0$ & \multirow{8}{*}{$\mathrm{NF}$} & 166.595 & 0.4031 & 239.414 & 10.048942 & 6.197 & 0.6332 & 28.6046 & 6.34985 & 5.2213 & 0.8884 & 30.4634 \\
\hline$\beta 1$ & & 127.285 & 6.8492 & 0.0013172 & 2.814995 & 32.966 & 5.1853 & 0.0034346 & 2.59113 & 24.2467 & 4.6765 & 0.002630 \\
\hline$\beta 2$ & & 20.807 & 48.2456 & 1.52355 & 0.974061 & 15.478 & 30.9578 & 0.988614 & 0.95636 & 11.5317 & 26.1975 & 0.874673 \\
\hline$\beta 3$ & & & 11.4903 & & & & 10.3769 & & & & 6.7641 & \\
\hline Syx & & 36.45 & 36.5717 & 34.09 & 18.6538 & 18.5514 & 18.5614 & 19.48 & 23.7542 & 23.4999 & 23.3315 & 24.19 \\
\hline $\mathrm{R}^{2}$ & & 0.756 & 0.7572 & 0.7256 & 0.8337 & 0.8356 & 0.8375 & 0.8186 & 0.7552 & 0.7604 & 0.7668 & 0.7461 \\
\hline AIC & & 162.7101 & 164.2484 & -78.7203 & 131.6369 & 130.7447 & 131.7867 & -129.414 & 188.8312 & 187.0235 & 186.7718 & -48.4751 \\
\hline BIC & & 172.6195 & 176.635 & & 141.2147 & 140.3225 & 143.759 & & 198.5545 & 196.7468 & 198.9259 & \\
\hline \multicolumn{13}{|c|}{ Crown area } \\
\hline$\overline{\beta 0}$ & 7.47379 & 3.904 & 0.1628 & 46.5849 & 4.44729 & 4.0187 & -0.3037 & 6.81112 & 9.98398 & 9.049 & -1.209 & 10.3606 \\
\hline$\beta 1$ & 7.42688 & 38.11 & 3.4931 & 0.0081659 & 8.14836 & 29.9784 & 4.1976 & 0.0356283 & 8.55359 & 27.205 & 9.906 & 0.076999 \\
\hline$\beta 2$ & 0.95653 & 7.529 & 37.1154 & 2.41311 & 0.91923 & 6.986 & 27.4131 & 2.67474 & 0.9154 & 6.691 & 26.585 & 6.15373 \\
\hline$\beta 3$ & & & 5.677 & & & & 8.3735 & & & & 9.344 & \\
\hline Syx & 62.37 & 61.86 & 62.02 & 63.28 & 61.2412 & 61.3799 & 61.7091 & 61.451 & 62.2728 & 62.5856 & 62.8072 & 62.23 \\
\hline $\mathrm{R}^{2}$ & 0.6897 & 0.6947 & 0.6968 & 0.5942 & 0.5032 & 0.501 & 0.5021 & 0.4998 & 0.5205 & 0.5156 & 0.5182 & 0.5210 \\
\hline AIC & 196.5916 & 195.1515 & 196.5544 & -22.5748 & 282.3096 & 282.6761 & 284.4976 & 51.0007 & 431.1570 & 431.9989 & 433.5491 & 190.6773 \\
\hline $\mathrm{BIC}$ & 206.5009 & 205.0609 & 208.9411 & & 291.8874 & 292.2539 & 296.4698 & & 440.8802 & 441.7222 & 445.7032 & \\
\hline \multicolumn{13}{|c|}{ Crown volume } \\
\hline$\overline{\beta 0}$ & \multirow{8}{*}{$\mathrm{NF}$} & \multirow{8}{*}{$\mathrm{NF}$} & \multirow{8}{*}{$\mathrm{NF}$} & 169.804 & 7.94643 & 7.664 & 0.02429 & 36.5132 & 35.19192 & 24.569 & -7.045 & 86.8015 \\
\hline$\beta 1$ & & & & 0.015 & 54.35 & 30. & 7.65958 & 0.0154251 & 5.92998 & 37.384 & 86.318 & 0.016167 \\
\hline$\beta 2$ & & & & 5.11997 & 0.86445 & 4.496 & 30.15917 & 2.31563 & 0.95478 & 9.593 & 72.933 & 2.49371 \\
\hline$\beta 3$ & & & & & & & 4.4668 & & & & 26.022 & \\
\hline Syx & & & & 88.71 & 91.6972 & 91.5237 & 92.1157 & 93.81 & 85.6672 & 85.9099 & 86.1274 & 85.58 \\
\hline $\mathrm{R}^{2}$ & & & & 0.5990 & 0.4051 & 0.4073 & 0.4073 & 0.3774 & 0.4317 & 0.4285 & 0.4327 & 0.432835 \\
\hline AIC & & & & 120.3324 & 441.9688 & 441.6619 & 443.6613 & 213.787 & 578.7292 & 579.2045 & 580.5857 & 338.1942 \\
\hline BIC & & & & & 451.5466 & 451.2397 & 455.6335 & & 588.4525 & 588.9278 & 592.7398 & \\
\hline
\end{tabular}

Note: $\mathrm{GO}=$ Gompertz's model; $\mathrm{LO}=$ Logistic model; LO $4 \mathrm{P}=$ Logistic 4 Parameters; $\mathrm{CP}=$ Chapman-Richard model; $\mathrm{NF}=$ no fitting; $\beta_{0}, \beta_{1}, \beta_{2}$ and $\beta_{3}=$ models parameters; $\mathrm{S}_{\mathrm{yx}}=$ standard error of the estimate $(\%) ; \mathrm{R}^{2}=$ coefficient of determination; AIC = Akaike's Information Criterion; BIC = Bayesian Information Criterion Nota: $G O=$ Gompertz; $L O=$ Logístico; $L O 4 P=$ Logístico 4 parâmetros; $C P=$ Chapman-Richard; $N F=$ sem ajuste; $\beta_{0}, \beta_{1}, \beta, e \beta_{3}=$ parâmetros dos modelos; $S_{y,}=$ erro padrão da estimativa (\%); $R^{2}=$ coeficiente de determinação; AIC = Critério de Informação Akaike; BIC = Critério de Informação Bayesiano.

The fitting of the models generated excellent statistics. For collar diameter and total height of all species as well as crown area of $A$. angustifolia, values of coefficient of determination higher than 0.65 were observed, with values above 0.72 for total height in all species. For these variables, besides total height and crown area of $A$. angustifolia, the values of Standard error were lower than $30 \%$, indicating a great growth projection for these variables performed by the tested models. On the other hand, higher Standard error values were noticed for crown area and volume, especially for crown volume, smaller coefficients of determination for such variables were observed as well, varying from 0.40 to 0.52 .

The species showed considerable initial growth for all variables in the first 48 months of age. Overall, 
they showed exponential growth over time, reaching the highest values at the end of the evaluation period (42 to 48 months), as expected; $P$. rigida showed the fastest growth.

Regarding the collar diameter, $P$. rigida (median of $70.97 \mathrm{~mm}$ at 48 months) and B. riedelianum (median of $61.56 \mathrm{~mm}$ at 42 months) reached the highest growth rates (Fig. 1). Both kept or even reduced their values of collar diameter at 12 months, probably as a response to the cold and dry winter of 2011, where minimum temperatures dropped to $-4^{\circ} \mathrm{C}$. Both species, at 36 months (after winter of 2013), showed again a slight decrease in collar diameter, most likely as a result of the low temperatures in that period, which reached $-2^{\circ} \mathrm{C}$. Araucaria angustifolia did not show significant decreases in collar diameter in both winters, showing resistance to colder temperatures since it naturally grows in regions with mesothermal climates and at elevations higher than $700 \mathrm{~m}$, where the temperature tends to be colder (Carvalho, 1981; Webb, et al., 1984).

In terms of total height, $P$. rigida (median of $4.475 \mathrm{~m}$ at 48 months) presented the highest rates, followed by $B$. riedelianum (median of $4.425 \mathrm{~m}$ at 42 months) and $A$. angustifolia with the lowest values (median value of $4.0 \mathrm{~m}$ at 48 months) (Fig. 2). For this variable, the frost in 2011 probably affected $B$.
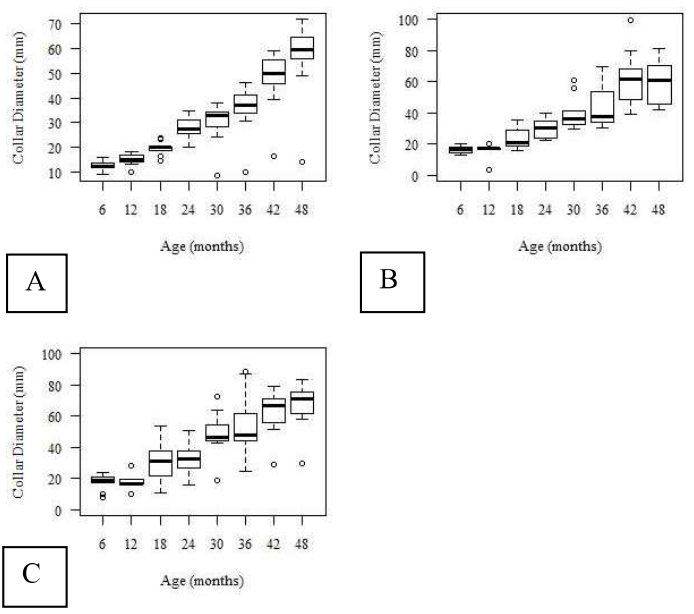

Figure 1 - Initial growth of the collar diameter of the species over time. A: Araucaria angustifolia, B: Balfourodendron riedelianum; $C$ : Parapiptadenia rigida.

Figura 1 - Crescimento inicial do diâmetro de colo das espécies ao longo do tempo. A: Araucaria angustifolia, B: Balfourodendron riedelianum; C: Parapiptadenia rigida.

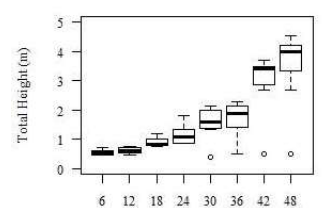

Age (months)
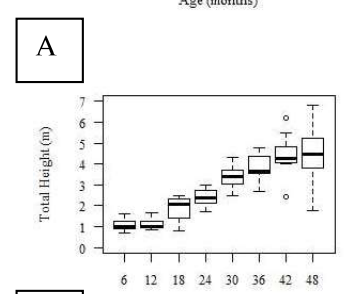

C Age (months)

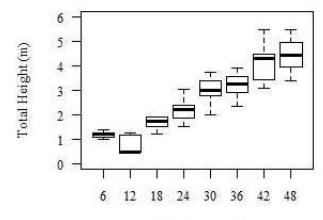

$\mathrm{B}$
Figure 2 - Initial growth of the total height of the species over time. A: Araucaria angustifolia, B: Balfourodendron riedelianum; C: Parapiptadenia rigida.

Figura 2-Crescimento inicial da altura total das espécies ao longo do tempo. A: Araucaria angustifolia, $B$ : Balfourodendron riedelianum; C: Parapiptadenia rigida.

riedelianum, while the cold temperatures in 2013 reduced the values of total height for $A$. angustifolia. Although the cold temperatures affected these two species in terms of total height, no decrease in this variable was noticed for $P$. rigida.

In terms of crown area, $P$. rigida (median of $10.35 \mathrm{~m}^{2}$ at 48 months) achieved rates around three times higher than $B$. riedelianum (median of $3.37 \mathrm{~m}^{2}$ at 42 months) and almost four times larger than $A$. angustifolia (median of $2.91 \mathrm{~m}^{2}$ at 42 months) (Fig. 3). For all species, the lowest values of crown area were noted in the first year; after that, a significant increase was observed, especially in $P$. rigida. Frost had no effect on crown area growth, irrespective of the species.

The behavior of crown volume for all species was similar to that of crown area (Fig. 4). In the first year, the crown volume of the three species was small, close to $0 \mathrm{~m}^{3}$, and increased from 18 months on, especially for $P$. rigida, which reached rates (median of 15.30 $\mathrm{m}^{3}$ at 48 months) significantly larger than those of $B$. riedelianum (median of $6.86 \mathrm{~m}^{3}$ at 42 months) and $A$. angustifolia (median of $6.02 \mathrm{~m}^{3}$ at 48 months).

\section{DISCUSSION}

The non-linear models tested to estimate growth in collar diameter, total height, crown area, and volume produced excellent statistics, especially

Revista Árvore 2019;43(4):e430404 


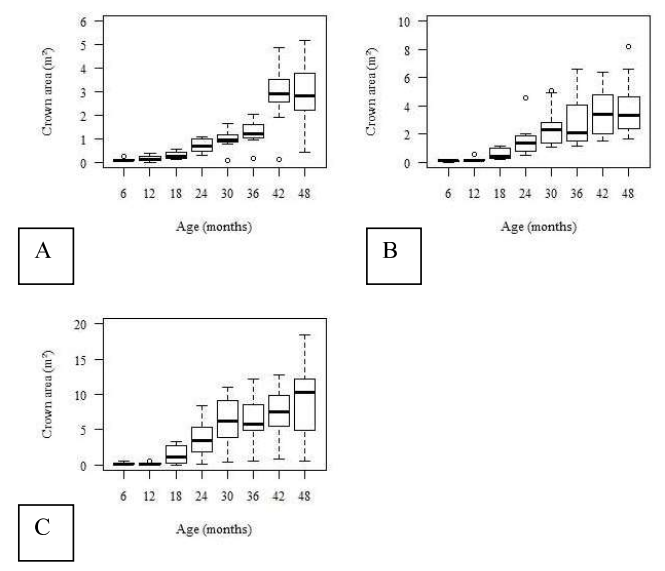

Figure 3 - Initial growth of the crown area of the species over time. A: Araucaria angustifolia, B: Balfourodendron riedelianum; C: Parapiptadenia rigida.

Figura 3-Crescimento inicial da área de copa das espécies ao longo do tempo. A: Araucaria angustifolia, $B$ : Balfourodendron riedelianum; C: Parapiptadenia rigida.
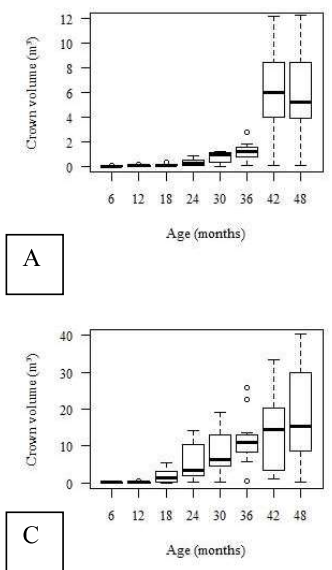

Figure 4 - Initial growth of the crown volume of the species over time. A: Araucaria angustifolia, B: Balfourodendron riedelianum; C: Parapiptadenia rigida.

Figura 4-Crescimento inicial do volume de copa das espécies ao longo do tempo. A: Araucaria angustifolia, B: Balfourodendron riedelianum; $C$ : Parapiptadenia rigida.

when compared to other studies. Hess, et al. (2009), using regression models, obtained coefficients of determination from 0.73 to 0.98 to estimate $\mathrm{dbh}$ as a function of age for A. angustifolia. Machado, et al. (2008), using regression to estimate height based on dbh for A. angustifolia, found coefficient of determination rates around 0.2 , which are considered very low.
Concerning growth modeling, there is an emerging consensus that traditional growth modeling, such as linear and exponential approaches, has become outdated. New technologies have facilitated the manipulation of non-linear models, which have the advantage that they consider different growth rates (Paine, et al., 2012).

Several studies have used nonlinear models to model the growth of some tree variables. For example, Calegario, et al. (2005) developed a non-linear mixedeffects model to represent the height growth pattern of eucalypts clonal stands in Brazil and described the non-linear modeling approach as flexible, precise, and accurate. Also, Misik, et al. (2016) tested 10 nonlinear height-diameter functions for dominant woody species in a temperate oak forest in Hungary, and Zhang (1997) fitted six non-linear growth functions to tree height-diameter data of six conifer species in the United States.

The non-linear functions used in this study have been widely applied to numerous data sets. For example, Zhang (1997), assessing the performance of non-linear models to tree height-diameter prediction of conifer trees in the United States, observed that the Gompertz function underestimated tree height for large-sized trees, while Richard's function as well as Schnute's and Weibull's functions produced the best predictions for his data set. Maia, et al. (2009), testing non-linear regression growth models for $\mathrm{Musa}$ spp. (banana), noticed that the best function was the logistic model. Scheeren, et al. (1999) found that the three-parameter Chapman-Richards model was the most precise model to estimate the height of $A$. angustifolia in terms of age.

Such results are in agreement with the idea that the models provide specific estimates according to the data set used, making it important to select the appropriate models and/or functions. When fitted to the data, many functions can provide similar results according to the data set used to estimate the equation's coefficients, but their behavior might change when extrapolated, depending on the mathematical properties (Burkhart and Tomé, 2012).

In terms of the growth behavior of the species, it is possible to associate their growth with their successional characteristics. While $B$. riedelianum is classified as a late secondary species, it has a slow 
to moderate growth, and although $P$. rigida could be denominated as initial secondary species, it shows a moderate to slow growth (Carvalho, 2003; Carvalho, 2002b). Araucaria angustifolia has been grouped into different successional categories, such as pioneer (Webb, et al., 1984; Klein, 1960), secondary (Imaguire, 1979), or even climax species (Duarte, et al., 2002), since it is an opportunistic species. However, it shows a relatively slow growth, especially in the first 3 years, with a subsequent increase in growth rate (Carvalho, 2002a).

In addition, it is necessary to emphasize the damage that frosts caused in the development of the individuals in this period, especially during the first and third years when winter was more severe. Frost, depending on the damage degree and on the species, could become a limiting factor for forests (Caron, et al., 2011). For example, Carvalho (2002b) states that $P$. rigida did not pursue a good performance in some cities in the south of Brazil due to the occurrence of frost. However, in our study, A. angustifolia, B. riedelianum, and $P$. rigida showed an increased growth after frost periods, suggesting a high resilience to cold temperatures and frost.

It is important to emphasize that, in order to acquire more information about these species' initial growth, it is necessary to extend the observation window as well as to conduct further studies in other subtropical regions, with other soil-climatic conditions and with more individuals. This was an initial performance study, which proved that mathematical models could be used to project the species' growth based on a data set.

\section{CONCLUSIONS}

Based on the results obtained in this study, it can be stated that:

- $\quad$. rigida presented a better performance in initial growth compared to $B$. riedelianum and $A$. angustifolia, behaving as a pioneer - initial secondary species;

- The models tested presented similar statistics for all variables considered, and their fitting generated excellent statistics, with better statistics for collar diameter and total height;

- It is statistically plausible to apply non-linear models to predict the initial growth of native species, but their performance depends on the data set, since a different model fitted better to each variable analyzed in this study;

- Longer monitoring in this and other experiments are recommended to characterize the initial growth of these three Brazilian native timber species and to better describe their performance in timber and forest restoration.

\section{REFERENCES}

Alvares CA, Stape JL, Sentelhas PC, Gonçalves JLM, Sparovek G. Köppen's climate classification map for Brazil. Meteorologische Zeitschrift. 2014;22(6):711-728.

Burkhart HE, Tomé M. Modeling forest trees and stands. New York: Springer; 2012.

Calegario N, Daniels RF, Maestri R, Neiva R. Modeling dominant height growth based on nonlinear mixed-effects model: a clonal Eucalyptus plantation case study. Forest Ecology and Management. 2005;204(1):11-21.

Caron BO, Souza VQ, Eloy E, Behling A, Schmidt D, Trevisan R. Resistência inicial de quarto espécies arbóreas em diferentes espaçamentos após ocorrência de geada. Ciência Rural. 2011;41(5):817-822.

Carvalho PER. Competição entre espécies florestais nativas em Irati-PR, cinco anos após o plantio. Boletim de Pesquisa Florestal. 1981; 2: 41-56.

Carvalho PER. Pinheiro-do-Paraná. Colombo, PR: Embrapa Forestas; 2002a.

Carvalho PER. Angico-gurucaia. Colombo, PR: Embrapa Forestas; 2002b.

Carvalho PER. Espécies arbóreas brasileiras. Brasília, DF: Embrapa Informação Tecnológica; Colombo, PR: Embrapa Forestas; 2003-2014. v. 5. (Coleção espécies arbóreas brasileiras).

Carvalho PER. Pau-marfim - Balfourodendron riedelianum. Colombo, PR: Embrapa Forestas; 2004.

Coradin L, Siminski A, Reis A. Espécies nativas da flora brasileira de valor econômico atual ou potencial: plantas para o futuro - Região Sul. Brasília, DF: MMA; 2011. 
Duarte LS, Dillenburg LR, Rosa LMG. Assessing the role of light availability in the regeneration of Araucaria angustifolia (Araucariaceae). Australian Journal of Botany. 2002; 50(6):741-751.

Empresa Brasileira de Pesquisa Agropecuária Embrapa. Sistema brasileiro de classificação de solos. Rio de Janeiro: CNPS; 2006.

Hess AF, Schneider PR, Finger CAG. Crescimento em diâmetro de Araucaria angustifolia (Bertol.) Kuntze em função da idade em três regiões do Rio Grande do Sul. Ciência Florestal. 2009; 19(1):7-22.

IAP - Instituto Ambiental do Paraná. Lista vermelha de plantas ameaçadas de extinção no Estado do Paraná. Curitiba: SEMA/GTZ; 1995.

Imaguire, N. Condições ambientais para a Araucaria angustifolia Bert. O. Ktze. Dusenia. 1979;11(3):121127.

International Union for Conservation of Nature and Natural Resources - IUCN. The Red List of Threatened Species. 2018. [Accessed on June 21]. Available from: http://www.iucnredlist.org/

Kageyama PO, Castro CFA. Sucessão secundária, estrutura genética e plantações de espécies arbóreas nativas. IPEF. 1989;41/42:83-93.

Machado SA, Nascimento RGM, Augustynczik ALD, Silva LCRS, Figura MA, Pereira EM, Téo J. Comportamento da relação hipsométrica de Araucaria angustifolia no capão da Engenharia Florestal da UFPR. Pesquisa Florestal Brasileira. 2008;56:5-16.

Maia E, Siqueira DL, Silva FF, Peternelli LA, Salomão LCC. Método de comparação de modelos de regressão não-lineares em bananeiras. Ciência Rural. 2009;39(5):1380-1386.

Misik T, Antal K, Kárász I, Tóthmérész B. Nonlinear height-diameter models for three woody, understory species in a temperate oak forest in Hungary. Canadian Journal of Forest Research. 2016;46(11):1337-1342.

Brasil. Portaria MMA No 443 de 17 de dez. de 2014 do Ministério do Meio Ambiente, dos Recursos hídricos e da Amazônia legal . Lista nacional oficial de espécies da flora ameaçadas de extinção. Brasília, 17 de dez. de 2014.

Mósena M, Dillenburg LR. Early growth of Brazilian pine (Araucaria angustifolia [Bertol.] Kuntze) in response to soil compaction and drought. Plant and Soil. 2004; 258(1):293-306.

Paine CET, Marthews TR, Vogt DR, Purves D, Rees M, Hector A, Turnbull LA. How to fit nonlinear plant growth models and calculate growth rate: an update for ecologists. Methods in Ecology and Evolution. 2012:3(2):245-256.

R Development Core Team. The R Project for Statistical Computing. 2017. R Foundation for Statistical Computing, Vienna, Austria. URL https:// www.r-project.org/.

Ruschel AR, Nodari ES, Guerra MP, Nodari RO. Evolução do uso e valorização das espécies madeiráveis da floresta estacional decidual do Alto Uruguai, SC. Ciência Florestal. 2003; 13(1):156-166.

Scheeren LW, Finger CAG, Schumacher MV, Longhi SJ. Crescimento em altura de Araucaria angustifolia (Bert.) O. Ktze. Em três sítios naturais, na região de Canela - RS. Ciência Florestal. 1999;9(2):23-40.

Soares RV. Considerações sobre a regeneração natural de Araucaria angustifolia. Floresta. $1979 ; 10(2): 12-18$.

Souza AF. Ecological interpretation of multiple population size structures in trees: The case of Araucaria angustifolia in South America. Austral Ecology. 2007; 32:524-533.

Webb DB, Wood PJ, Smith JP, Henman GS. A guide to species selection for tropical and sub-tropical plantations. Tropical Forestry Papers. 1984;(15).

Zandavalli RB, Dillenburg LR, Souza PVD. Growth responses of Araucaria angustifolia (Araucariaceae) to inoculation with the mycorrhizal fungus Glomus clarum. Applied Soil Ecology. 2004;25(3):245-255.

Zhang L. Cross-validation of non-linear growth functions for modeling tree height-diameter relationships. Annals of Botany. 1997;79(3):251-257. 
Revista Árvore 2019;43(4):e430404 